\title{
A Preliminary Survey on the Knowledge and Technique of Midline Abdominal Wall Closure among General Surgeons
}

\author{
Jose Macario V. Faylona
}

Department of Surgery, College of Medicine and Philippine General Hospital, University of the Philippines Manila

\begin{abstract}
Objective. This preliminary survey aims to determine the depth of knowledge and preference for technique in midline abdominal wall closure among general surgeons.

Methods. A random survey among general surgeons was done during the Philippine College of Surgeons Annual Convention last December 2013. The results were analyzed and compared with published literature on abdominal wall closure and the proper technique of closure.

Results. There were 36 respondents: 17 (48.6\%) residents and 18 (51.4) consultants, $85.7 \%$ of whom said they learned closure as taught by their seniors or consultants, $82.8 \%$ said they close the abdomen using a continuous suture technique and $57.1 \%$ said they apply an interlocking stitch. The most popular suture material used for closure is an absorbable suture with long dissolution time (71.4\%). 51.4\% put their sutures at 5-9 mm intervals and $40 \%$ put the sutures at $5-9 \mathrm{~mm}$ or $1 \mathrm{~cm}$ or more from the edge of the wound. $51.4 \%$ close the subcutaneous tissue and $94.2 \%$ do not place subcutaneous drains.

Conclusion. In this preliminary survey, both consultants and residents learned closure by being taught by their seniors. Knowledge and techniques of closure were adequate but were inconsistent with reported literature. This demonstrates a possible inadequacy in the knowledge and skills training with regard to midline laparotomy closure.
\end{abstract}

Key Words: laparotomy, abdominal wound closure techniques, survey

Corresponding author: Jose Macario V. Faylona, MD

Department of Surgery

Philippine General Hospital

University of the Philippines Manila

Taft Avenue, Ermita, Manila 1000 Philippines

Telefax: +632 5673011

Email: mackymd@yahoo.com
Introduction

Closure of an abdominal wall incision is one of the most important aspects in surgery. Without proper knowledge of midline laparotomy closures and techniques of closure, there is a risk of evisceration and incisional hernia formation. The risk of evisceration has been reported to range from $0.6-2.5 \%$ in literature. ${ }^{1-8}$ The risk of incisional hernia formation has been reported to be $9-23 \% .^{9-12}$ Among the different incisions used in the abdominal wall to gain access to the abdominal cavity, the midline incision is the most commonly used. ${ }^{13}$ Proper abdominal wound closure of the laparotomy wound entails the proper use of suture materials and a closure technique standardized in terms of the size of the bites and the distance between stitches. No literature on how surgeons learn abdominal wound closure were found after a thorough search of Pubmed, Medline, and Medscape databases using the search terms "surgical residency", "surgical curriculum", "learning", and "abdominal wall closure".

Incisional hernia formation is one of the most common complications of failure of abdominal wound closure. There are different factors that may contribute to incisional hernia formation. There are patient factors such as smoking, older age, obesity, and malignancy. ${ }^{14,15}$ It has also been reported that the ratio of mature to immature collagen also places a role in incisional hernia formation. ${ }^{16}$ Wound factors that may contribute to incisional hernia formation such as wound infection as well as the type of surgery performed. ${ }^{17-19}$ There are also technical factors which may play a role, such as the closure technique of the surgeon, the type of suture used, the size of the suture bites and the use of drains. ${ }^{20}$

Patient factors are difficult to control and can only be corrected or optimized for better patient results. However, technical factors can be corrected and standardized to decrease the adverse events that may occur after closure of the abdominal wall.

Since technical factors can be controlled, it is important that a specific training program should be present in the training program of general surgery residents to ensure that the required knowledge and skill of abdominal wall closure is properly taught.

This preliminary study aims to look at the knowledge acquisition and the technique of closure of midline abdominal incisions among general surgeons using a survey questionnaire as a guide in the conduct of a more extensive 
survey. An in-depth review of literature was also done to look at the latest evidence on the proper approach to abdominal wall closure as well as healing of laparotomies.

\section{Methods}

This is a preliminary survey on the knowledge and technical skills of general surgeons. The survey questionnaire is composed of 10 items that look into how surgeons learn abdominal wall closure, their technique, the type of suture material used, the utilization of drains, and type of skin closure (Table 1). A selection of options was presented for each question.

Table 1. Survey on Midline Laparotomy Closure among General Surgeons

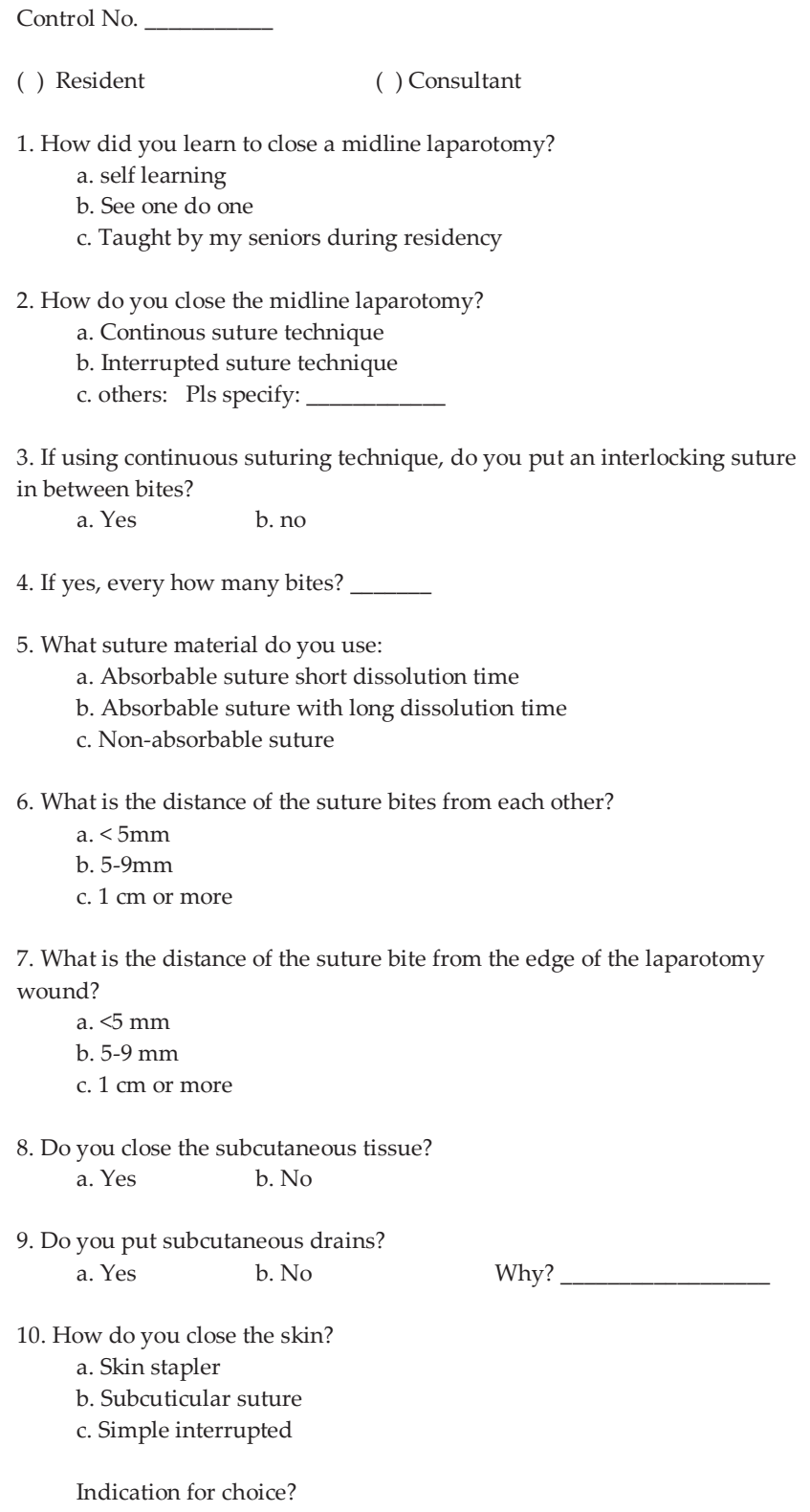

7. What is the distance of the suture bite from the edge of the laparotomy wound?

a. $<5 \mathrm{~mm}$

b. 5-9 $\mathrm{mm}$

c. $1 \mathrm{~cm}$ or more

8. Do you close the subcutaneous tissue?

$\begin{array}{ll}\text { a. Yes } \quad \text { b. No } & \text {. }\end{array}$

9. Do you put subcutaneous drains?
a. Yes
b. No
Why?

10. How do you close the skin?

a. Skin stapler

b. Subcuticular suture

c. Simple interrupted

Indication for choice?

The Philippine College of Surgeons (PCS) Annual Convention has an average attendance of 400 consultants and 300 residents. To pilot test the survey, 100 questionnaires were distributed in one of the hospitality suites during the convention. The forms were handed out as the surgeons attending the convention entered the suite and collected as they departed. The questionnaires were tagged using control numbers and the responders remained anonymous. There was no time limit imposed for answering the questionnaires. The results were then collated and analyzed using the following parameters:

1. Acquisition of knowledge in abdominal wall closure

2. Technique of midline closure

3. Use of interlocking stitch in the closure

4. Type of suture material used

5. Distance of suture bites from the edge of the laparotomy wound

6. Distance of suture bites from each other

7. Use of subcutaneous drains

8. Closure of subcutaneous tissue

9. Closure of the skin

Data was analyzed using the Statistical Package for the Social Sciences (SPSS) statistical software to evaluate differences in the responses of the residents and consultants.

\section{Results}

There were 36 respondents to the survey: 17 (48.6\%) residents and 18 (51.4) consultants. One respondent did not complete the survey and was not included in the analysis.

The majority of respondents learned closure by being taught by their seniors or consultants during residency $(85.7 \%)$. There was no significant difference between the answers of residents and consultants with a p-value of 0.511 . (Table 2)

In terms of closure technique, the majority of respondents said they close the abdomen with a continuous suture technique $(82.8 \%)$. Of the surgeons who said they close the abdomen with a continuous suturing technique, $57.1 \%$ said they place an interlocking stitch while $34.3 \%$ said they do not. Comparing the response of residents and consultants in terms of the placement of an interlocking stitch, the majority of residents place one every three to four bites $(70 \%) ; 40 \%$ of consultants use a similar technique. However, the data did not show any significant difference statistically.

In terms of the suture material used for closure of a midline laparotomy, $71.4 \%$ of respondents said they use a suture which is absorbable with a long dissolution time and $22.8 \%$ said they use a non-absorbable suture. 
Midline Closure among General Surgeons

Table 2. Tabulation of Response

\begin{tabular}{|c|c|c|c|c|c|}
\hline & & RESIDENT & CONSULTANT & TOTAL & \\
\hline Number & & $17(48.6 \%)$ & $18(51.4 \%)$ & $35(100 \%)$ & \\
\hline \multirow{4}{*}{$\begin{array}{l}\text { How did you learn to } \\
\text { close a midline } \\
\text { laparotomy }\end{array}$} & Self learning & 0 & $1(5.5 \%)$ & $1(2.8 \%)$ & \\
\hline & See one do one & 0 & $1(5.5 \%)$ & $1(2.8 \%)$ & \\
\hline & Taught by my seniors/consultant during residency & $15(88.2 \%)$ & $15(83.3 \%)$ & $30(85.7 \%)$ & \\
\hline & See one do one and taught by seniors & $2(11.8 \%)$ & $1(5.5 \%)$ & $3(8.6 \%)$ & p 0.511 \\
\hline \multirow{4}{*}{$\begin{array}{l}\text { How do you close a } \\
\text { midline laparotomy }\end{array}$} & Continuous suture Technique & $14(82.3 \%)$ & $15(83.3 \%)$ & $29(82.8 \%)$ & \\
\hline & Interrupted suture technique & $1(5.9 \%)$ & $2(11.1 \%)$ & $3(8.5 \%)$ & \\
\hline & Continuous with interrupted & $2(11.8 \%)$ & $1(5.5 \%)$ & $3(8.5 \%)$ & \\
\hline & No Answer & 0 & 0 & 0 & $\mathrm{p} 0.714$ \\
\hline \multirow{4}{*}{$\begin{array}{l}\text { If using continuous } \\
\text { suturing technique do } \\
\text { you put an interlocking } \\
\text { suture in-between bites? }\end{array}$} & Yes & $10(58.8 \%)$ & $10(55.5 \%)$ & $20(57.1 \%)$ & \\
\hline & No & $6(35.3 \%)$ & $6(33.3 \%)$ & $12(34.3 \%)$ & \\
\hline & No answer & 0 & 0 & 0 & \\
\hline & Not applicable & $1(5.9 \%)$ & $2(11.1 \%)$ & $3(8.6 \%)$ & P 0.682 \\
\hline \multirow{8}{*}{$\begin{array}{l}\text { If yes, every how many } \\
\text { bites? }\end{array}$} & 1 to 2 & $3(17.6 \%)$ & $1(5.5 \%)$ & $4(11.4 \%)$ & \\
\hline & 3 to 4 & $7(41.2 \%)$ & $4(22.2 \%)$ & $11(31.4 \%)$ & \\
\hline & 5 to 6 & 0 & $1(5.5 \%)$ & $1(2.8 \%)$ & \\
\hline & 7 to 10 & 0 & $1(5.5 \%)$ & $1(2.8 \%)$ & \\
\hline & Above 10 & 0 & 0 & 0 & \\
\hline & Depends & 0 & $1(5.5 \%)$ & $1(2.8 \%)$ & \\
\hline & Not applicable & $7(41.2 \%)$ & $8(44.4 \%)$ & $15(42.8 \%)$ & \\
\hline & No answer & 0 & $2(11.1 \%)$ & $2(5.7 \%)$ & p 0.325 \\
\hline \multirow{6}{*}{$\begin{array}{l}\text { What suture material do } \\
\text { you use? }\end{array}$} & Absorbable suture with short dissolution time & 0 & 0 & 0 & \\
\hline & Absorbable suture with long dissolution time & $12(70.5 \%)$ & $13(72.2 \%)$ & $25(71.4 \%)$ & \\
\hline & Non absorbable suture & $4(23.5 \%)$ & $4(22.2 \%)$ & $8(22.8 \%)$ & \\
\hline & Combined absorbable with long dissolution + non absorbable & 0 & $1(5.5 \%)$ & $1(2.8 \%)$ & \\
\hline & No answer & $1(5.9 \%)$ & 0 & $1(2.8 \%)$ & \\
\hline & Not applicable & 0 & 0 & 0 & P 0.630 \\
\hline \multirow{3}{*}{$\begin{array}{l}\text { What is the distance of } \\
\text { the suture bites from } \\
\text { each other? }\end{array}$} & $<5 \mathrm{~mm}$ & $5(29.4 \%)$ & $2(11.1 \%)$ & $7(20 \%)$ & \\
\hline & $5-9 \mathrm{~mm}$ & $8(47.1 \%)$ & $10(55.5 \%)$ & $18(51.4 \%)$ & \\
\hline & $1 \mathrm{~cm}$ or more & $4(23.5 \%)$ & $6(33.3 \%)$ & $1028.6 \%)$ & $\mathrm{p} 0.390$ \\
\hline \multirow{4}{*}{$\begin{array}{l}\text { What is the distance of } \\
\text { the suture bite from the } \\
\text { edge of the laparotomy } \\
\text { wound? }\end{array}$} & $<5 \mathrm{~mm}$ & $4(23.5 \%)$ & $3(16.7 \%)$ & $7(20 \%)$ & \\
\hline & $5-9 \mathrm{~mm}$ & $8(70.5 \%)$ & $6(33.3 \%)$ & $14(40 \%)$ & \\
\hline & $1 \mathrm{~cm}$ or more & $5(29.4 \%)$ & $9(50 \%)$ & $14(40 \%)$ & \\
\hline & Not applicable & 0 & 0 & 0 & p 0.426 \\
\hline \multirow{4}{*}{$\begin{array}{l}\text { Do you close the } \\
\text { subcutaneous tissue? }\end{array}$} & Yes & $8(47 \%)$ & $10(55.5 \%)$ & $18(51.4 \%)$ & \\
\hline & No & $9(53 \%)$ & $6(33.3 \%)$ & $15(42.8 \%)$ & \\
\hline & NA & 0 & $1(5.5 \%)$ & $1(2.8 \%)$ & \\
\hline & Depends on thickness & 0 & $1(5.5 \%)$ & $1(2.8 \%)$ & p 0.359 \\
\hline \multirow{3}{*}{$\begin{array}{l}\text { Do you put } \\
\text { subcutaneous drains }\end{array}$} & Yes & $2(11.8 \%)$ & 0 & $2(5.7 \%)$ & \\
\hline & No & $15(88.2 \%)$ & $18(100 \%)$ & $33(94.3 \%)$ & \\
\hline & Not applicable & 0 & 0 & 0 & p 0.134 \\
\hline \multirow{9}{*}{$\begin{array}{l}\text { How do you close the } \\
\text { skin? }\end{array}$} & Skin stapler & $7(41.2 \%)$ & $6(33.3 \%)$ & $13(37.1 \%)$ & \\
\hline & Subcuticular suture & $6(35.3 \%)$ & $4(22.2 \%)$ & $10(28.6 \%)$ & \\
\hline & Simple Interrupted & $1(5.9 \%)$ & 0 & $1(2.8 \%)$ & \\
\hline & No answer & $1(5.9 \%)$ & 0 & $1(2.8 \%)$ & \\
\hline & Uses all depending on the wound & $1(5.9 \%)$ & $1(5.5 \%)$ & $2(5.7 \%)$ & \\
\hline & Subdermal inverted interrupted & $1(5.9 \%)$ & $1(5.5 \%)$ & $2(5.7 \%)$ & \\
\hline & Subcuticular or simple interrupted & 0 & $1(5.5 \%)$ & $1(2.8 \%)$ & \\
\hline & Stapler or subcuticular & 0 & $4(27.8 \%)$ & $4(11.4 \%)$ & \\
\hline & Stapler or simple interrupted & 0 & $1(5.5 \%)$ & $1(2.8 \%)$ & p 0.529 \\
\hline
\end{tabular}


Of the residents, $47 \%$ said they place the sutures at 5-9 $\mathrm{mm}$ from each other and 5-9 $\mathrm{mm}$ from the edge of the wound. Of the consultants, $55.5 \%$ said they place the sutures at $5-9 \mathrm{~mm}$ from the edge of the laparotomy wound and 50\% place them at $1 \mathrm{~cm}$ from the edge of the laparotomy wound. This difference did not reach statistical significance $(\mathrm{p}=0.426)$.

Of the respondents, $51.4 \%$ said they close the subcutaneous tissue and $42.8 \%$ said they do not. Further analysis reveals that closure of the subcutaneous tissue is more popular among consultants (55.5\%) than among residents (47\%). Neither consultants nor residents say they place drains in the subcutaneous tissue.

Both residents and consultants varied in their responses in terms of skin closure. The majority of respondents said they close the skin either with a skin stapler or using a subcuticular technique. Analysis of the data reveals some differences in the responses but this failed to reach statistical significance.

\section{Discussion}

This research on abdominal wall closure aims to look into minimizing incisional hernia formation. Incisional hernia formation is influenced by several factors such as patient-related factors and surgical technique. ${ }^{21}$ Patientrelated factors are difficult to control but knowing the possible risk factors will alert the surgeon of the possible risk of incisional hernia formation postoperatively. On the other hand, surgical technique can be standardized such that the risk of incisional hernia formation is decreased.

\section{Technique of Closure}

Our results showed that the majority of surgeons close the abdomen with a continuous suture. This practice conforms with current evidence that shows that using a continuous suture has better results compared with interrupted sutures due to the even distribution of the tension along the entire length of the laparotomy wound. ${ }^{22,23}$ An interrupted technique has the advantage of not being dependent on a single knot compared with the continuous technique; however, it suffers from potential inconsistencies in the tightness of each knot thrown by the surgeon. Inconsistencies in the tension will subject the laparotomy wound to possible tissue ischemia with subsequent necrosis of the wound edge, which in turn can result in wound infection or incisional hernia formation.

Of the respondents, $69 \%$ said they place an interlocking suture between several bites of a continuous suture. This technique is not described in the literature. ${ }^{24-30}$ Frequently used by the respondents, the technique is most likely handed down to them by senior residents or consultants during their training. This practice is not supported by literature and should be abandoned since knot slippage rarely occurs in the continuous suture technique. ${ }^{31}$
The choice of suture material also plays a role in the occurrence of incisional hernia. Rath hypothesized that the ideal suture material for laparotomy closure should maintain at least half of its strength during the 4 or 5 months following the operation. ${ }^{32}$ Rapidly absorbable sutures have no role in laparotomy closure. The literature only supports the use of sutures that are slowly absorbable or nonabsorbable for closure of midline laparotomies. The only drawback to using a non-absorbable suture is the higher incidence of wound pain and suture sinuses. ${ }^{33}$ None of the respondents said they use a rapidly absorbable suture.

The majority of respondents said they place the stitch at 5-9 $\mathrm{mm}$ from the edge of the laparotomy. More residents said they place the sutures at intervals of 5-9 $\mathrm{mm}$ while more consultants said they place the sutures at intervals of 1 $\mathrm{cm}$ or greater. This demonstrates the poor knowledge of the respondents in terms of the proper positioning of the stitches in a laparotomy wound. Using shorter intervals between suture bites requires longer sutures to complete the closure.

The suturing technique of the surgeon is important to achieve consistency of suture placement. This is important to decrease the possibility of incisional hernia formation. Consistency is only achieved if the suture length is enough for the wound length. If the suture is too short for the wound, the surgeon may compensate toward the end of closure by placing the stitches further and further apart. 7 , 22, 23,33,34-36

The size of the tissue bites and the distance of the stitches from each other also affects tissue healing, wound infection, and incisional hernia formation. In an animal study, Felcher et al. associated small tissue bites with a stronger wound 4 days after closure. ${ }^{37}$ Further clinical trials showed that the stitches should be placed at $5-8 \mathrm{~mm}$ from the edge of the laparotomy wound at intervals of less than 5 $\mathrm{mm} .{ }^{7,38-41}$

The majority of respondents in this study said they place the sutures bites at intervals of $5-9 \mathrm{~mm} ; 29 \%$ said they place them at intervals of $1 \mathrm{~cm}$ or more. This is inconsistent with literature which states that aside from trying to achieve an SL:WL ratio of $4: 1$, surgeons should also try to achieve a shorter stitch length which is associated with a lower chance of wound infection and incisional hernia formation. ${ }^{41,42}$ The mean stitch length is computed by getting the ratio of the suture length and the number of stitches (SL: \# of stitches). Achieving a shorter mean stitch length means more consistent suturing and also placement of stitches at intervals of less than $5 \mathrm{~mm}$.

The majority of consultants responding to the study said they close the subcutaneous tissue, which is not popular among the residents. Current evidence on subcutaneous closure shows that there is no benefit to closing the subcutaneous tissue. ${ }^{43,44}$ Both residents and consultants are in agreement that subcutaneous drains are unnecessary. This is supported by evidence that placement of closed suction 
drainage in the subcutaneous tissue does not prevent significant wound complications. ${ }^{45,46}$

Our respondents performed skin closure either with skin staplers or with subcuticular sutures. The literature shows advantages and disadvantages to either technique. Subcuticular sutures provide more comfort for the patient since absorbable sutures eliminate the need for removal; however, in some cases, the sutures may be extruded if they are not fully absorbed.

Skin staples have the advantage of faster, easier deployment. Staples can also be removed one at a time to open up the wound if a surgical site infection develops. Staples provide an acceptable cosmetic result and are associated with a low rate of infection. ${ }^{47}$

This survey showed inconsistencies in the knowledge and skill of the respondents in comparison with published literature on proper abdominal wound closure. According to the Philippine Society of General Surgeons (PSGS) Residency Manual, training of general surgery residents is mainly based on performance of certain procedures and operations. ${ }^{48}$ Wound closure is one of the skills in basic surgery that a trainee should learn and master. However, further review of the manual did not specify how this is to be done and at what year level in the training program it should be learned and mastered. It is implied that as the trainee learns certain abdominal operations, the trainee will also learn closure of abdominal wall incisions. Without a proper curriculum and practice simulations in either a dry lab or an animal model, closure of laparotomies will always be inconsistent and the knowledge and skill of laparotomy closure will be dependent on what the surgeon mentors teach.

This preliminary study was conducted to evaluate how general surgeons learn abdominal wall closure. The majority of surgeons in our survey learned closure by being taught by their seniors or consultants $(85.7 \%)$. A senior resident or consultant teaches the trainee by demonstrating how they close a laparotomy wound during actual surgery. Unless checked against an established standard or curriculum, this teaching strategy perpetuates the use of erroneous surgical techniques. To confirm that abdominal wound closure is mainly learned in this manner, the full survey should aim to include at least 185 respondents. The full survey should also include the surgeon's awareness and practice of abdominal wound closure in terms of suture-to-wound length ratio and stitch length.

\section{Conclusion}

This preliminary survey showed that both surgical consultants and residents learned closure by being taught by their seniors. Knowledge and techniques of closure were adequate in practical terms but were inconsistent with reported literature. This demonstrates inadequacy in training with regards to midline laparotomy closure.

\section{References}

1. Binnie NR, Bainbridge CL, Macintyre IM. Abdominal wound closure with polydioxanone (PDS). J R Coll Surg Edinb. 1986; 31(3):147-50.

2. Wissing J, van Vroonhoven TJ, Schattenkerk ME, Veen HF, Ponsen RJ, Jeekel J. Fascia closure after midline laparotomy: results of a randomized trial. Br J Surg. 1987; 74(8):738-41.

3. Senbanjo RO, Ayayi OO. Abdominal wound dehiscence: a review of 60 cases at the University College Hospital, Ibadan. Afr J Med Sci. 1988; 17(3):133-40.

4. Gys T, Hubens A. A prospective comparative clinical study between monofilament absor- bable and non-absorbable sutures for abdominal wall closure. Acta Chir Belg. 1989; 89(5):265-70.

5. Lewis RT, Wiegand FM. Natural history of vertical abdominal parietal closure: Prolene versus Dexon. Can J Surg. 1989; 32(3):196-200.

6. Trimbos JB, Smit IB, Holm JP, Hermans J. A randomized clinical trial comparing two methods of fascia closure following midline laparotomy. Arch Surg. 1992; 127(10):1232-4.

7. Israelsson LA, Jonsson T. Suture length to wound length ratio and healing of midline Iaparotomy incisions. Br J Surg. 1993; 80(10):1284-6.

8. Carlson MA, Condon RE. Polyglyconate (Maxon) versus nylon suture in midline abdominal incision closure: a prospective randomized trial. Am Surg. 1995; 61(11):980-3.

9. Bucknall TE, Cox PJ, Ellis H. Burst abdomen and incisional hernia: a prospective study of 1129 major laparotomies. Br Med J. 1982; 284(6320):931-3.

10. Mudge M, Hughes LE. Incisional hernia: a 10 year prospective study of incidence and attitudes. Br J Surg. 1985; 72(1):70-1.

11. Israelsson LA, Jonsson T. Incisional hernia after midline laparotomy: a prospective study. Eur J Surg. 1996; 162(2):125-9.

12. Osther PJ, Gjode P, Mortensen BB, Mortensen PB, Bartholin J, Gottrup F. Randomized comparison of polyglycolic acid and polyglyconate sutures for abdominal fascial closure after laparotomy in patients with suspected impaired wound healing. Br J Surg. 1995; 82(8):1080-2.

13. Rahbari NN, Knebel P, Diener MK, et al. Current Practice of abdominal wall closure in elective surgery-is there any consensus? BMC Surg. 2009; 9:8.

14. Sorensen LT, Hemmingsen UB, Kirkeby LT, Kallehave F, Jorgensen LN. Smoking is a risk factor for incisional hernia. Arch Surg. 2005; 140(2):119-23.

15. Hoer J, Lawong G, Klinge U, Schumpelick V. Factors influencing the development of incisional hernia. A retrospective study of 2, 983 laparotomy patients over a period of 10 years. Chirurg. 2002; 73(5):47480 .

16. Hoer JJ, Junge K, Schachtrupp A, Klinge U, Schumpelick V. Influence of laparotomy closure technique on collagen synthesis in the incisional region. Hernia. 2002; 6(3):93-8.

17. da Silva AL, Petroianu A. Incisional hernias: factors influencing development. South Med J. 1991; 84(12):1500, 1504.

18. Santora TA, Roslyn JJ. Incisional hernia. Surg Clin North Am. 1993; 73(3):557-70.

19. Yahchouchy-Chouillard E, Aura T, Picone O, Etienne JC, Fingerhut A. Incisional hernias. Related risk factors. Dig Surg. 2003; 20(1):3-9.

20. Rath AM, Chevrel JP. The healing of laparotomies: a bibliographic study. Part two: technical aspects. Hernia. 2000; 4(1):41-8.

21. Schumpelick V, Junge $\mathrm{K}$, Klinge U, Conze J. Incisional Hernia: Pathogenesis, presentation and treatment. Dtsch Arztebl. 2006; 103(39):A2553-8.

22. Weiland DE, Bay RC, Del Sordi S. Choosing the best abdominal closure by meta-analysis. Am J Surg. 1998; 176(6):666-70.

23. Hodgson NC, Malthaner RA, Ostbyte T. The search for an ideal method of abdominal fascial closure, a meta-analysis. Ann Surg. 2000; 231(3):436-42.

24. Stone HH, Hoefling SJ, Strom PR, Dunlop WE, Fabian TC. Abdominal incisions: transverse vs. vertical placement and continuous vs. interrupted closure. South Med J. 1983; 76(9):1106-8. 
25. Sheperd JH, Cavanagh D, Riggs D, Praphat H, Wisniewiski BJ, Abdominal wound closure using a non absorbable single layer technique. Obstet Gynecol. 1983; 61(2):248-52.

26. McNeil PM, Sugerman HJ. Continuous absorbable vs. interrupted non absorbable fascial closure. A prospective randomized comparison. Arch Surg. 1986; 121(7):821-3.

27. Wadstrom J, Gerdin B. Closure of the abdominal wall; how and why? Clinical review. Acta Chir Scand. 1990; 156(1):75-82.

28. Trimbos JB, Smit JB, Holm JP, Hermans J. A randomized clinical trial comparing two methods of fascia closure following midline laparotomy. Arch Surg. 1992; 127(10):1232-4.

29. Niggerbrugge AH, Hansen BE, Trimbos JB, van de Velde CJ, Zwaveling A. Mechanical factors influencing the incidence of burst abdomen. Eur J Surg. 1995; 161(9):655-61.

30. Colombo M, Maggioni A, Parma G, Scalambrino S, Milani R. A randomized comparison of continuous versus interrupted mass closure of midline incisions in patients with gynecologic cancer. Obstet Gynecol. 1997; 89 (5 Pt 1):684-9.

31. Gislason H, Gronbech JE, Soreide O. Burst abdomen and incisional hernia after major gastrointestinal operations-comparison of three closure techniques. Eur J Surg. 1995; 161(5):349-54.

32. Rath AM, Chevrel JP. The healing of laparotomies: review of the literature. Part 1: Physiologic and pathologic aspects. Hernia. 1998; 2:145-9.

33. Van 't Riet M, Steyerberg EW, Nellensteyn J, Bonjer HJ, Jeekel J. Metaanalysis of techniques for closure of midline abdominal incisions. Br J Surg. 2002; 89(11):1350-6.

34. Hoer J, Anurov M, Titkova S, et al. Influence of suture material and suture technique on collagen fibril diameters in midline laparotomies. Eur Surg Res. 2000; 32(6):359-67.

35. Rucinski J, Margolis M, Panagopoulus G, Wise L. Closure of the abdominal midline fascia: Meta-analysis delineates the optimal technique. Am Surg. 2001; 67(5):421-6.

36. Diener MK, Voss S, Jensen K, Buchler MW, Seiler CM. Elective midline laparotomy closure: the INLINE systematic review and meta-analysis. Ann Surg. 2010; 251(5):843-56.

37. Felcher A, Schwartz J, Shechter C, Levenson SM, Demetriou AA. Wound healing in normal and analbuminemic (NAR) rats. J Surg Res. 1987; 43(6):546-9.

38. Cengiz Y, Blomquist P, Israelsson LA. Small tissue bites and wound strength: an experimental study. Arch Surg. 2001; 136(3):272-5.

39. Cengiz Y, Gislason H, Svanes K, Israelsson LA. Mass closure technique: an experimental study on separation of wound edge. Eur J Surg. 2001; 167(1):60-3.

40. Millbourn D, Israelsson LA. Wound complications and stitch length. Hernia. 2004; 8(1):39-41.

41. Harlaar JJ, van Ramshorst GH, Nieuwenhuizen J, et al. Small stitches with small suture distances increase laparotomy closure strength. Am J Surg. 2009; 198(3):392-5.

42. Millbourn D, Cengiz Y, Israelsson LA. Risk factors for wound complications in midline abdominal incisions related to the size of the stitches. Hernia. 2011; 15(3):261-6.

43. Cardosi RJ, Drake J, Holmes S, et al. Subcutaneous management of vertical incisions with 3 or more centimeters of subcutaneous fat. Am J Obstet Gynecol. 2006; 195(2):607-14.

44. Paral J, Ferko A, Varga J, et al. Comparison of sutured versus non sutured subcutaneous fat tissue in abdominal surgery. A prospective randomized study. Eur Surg Res. 2007; 39(6):350-8.

45. Hellums EK, Lin MG, Ramsey PS. Prophylactic subcutaneous drainage for prevention of wound complications after cesarean delivery- a metaanalysis. Am J Obstet Gynecol. 2007; 197(3):229-35.

46. Gates S, Anderson ER. Wound drainage for caesarian section. Cochrane Database Syst Rev. 2005; (1):CD004549.

47. Edlich RF, Becker DG, Thacker JG, Rodeheaver GT. Scientific basis for selecting staple and tape skin closures. Clin Plast Surg. 1990; 17(3):571-8.

48. Standardized Curriculum in General Surgery 2012. 4th edition. Philippine Society of General Surgeons. 2012. 